\title{
Ecobrick: solusi cerdas dan kreatif untuk mengatasi sampah plastik
}

\author{
Sekartaji Suminto* \\ Program Studi Desain Produk, Institut Seni Indonesia Yogyakarta, Indonesia
}

\begin{abstract}
Plastics are widely used in various needs of human life, starting from food wrapping material to the needs of automotive materials. Plastic is the most popular material and most widely used as a material for automotive component making, in addition to metal in the form of iron. The most important problem of plastics is the plastic waste that can not decompose naturally. It takes a very long time to clean up plastic waste from the face of the earth, especially since the use of plastic is almost unmanageable. Plastics also make the air temperature hotter day by day, due to its non-porous polymeric properties. At the moment, most products are produced without thinking of where they are going when consumed. Many products are also designed to fail within a certain period known as "planned obsolescence". This design philosophy is the cause behind overflowing landfills, plastic islands in the sea, and becoming a scourge such as packaging and products that clog the local ecosystem. Ecobrick is one of the creative efforts to manage plastic waste into useful objects, reducing pollution and toxins caused by plastic waste. Ecobrick is one of the creative endeavors for handling plastic waste. Its function is not to destroy plastic waste, but to extend the life of these plastics and process them into something useful, which can be used for the benefit of humans in general. Making ecobrick is still not so popular among the wider community. Most people still treat used plastics as household plastic waste, pollute the environment, rivers and pollute everyday life without self-awareness.
\end{abstract}

Keywords: plastic waste, contamination, ecobrick, creative effort

\begin{abstract}
Abstrak
Plastik banyak digunakan dalam berbagai macam kebutuhan hidup manusia. Mulai dari bahan pembungkus makanan hingga keperluan bahan otomotif. Plastik merupakan sebuah bahan yang paling populer dan paling banyak digunakan sebagai bahan pembuat komponen otomotif selain bahan logam berupa besi. Permasalahan yang paling utama dari plastik adalah limbah plastik yang tidak bisa terurai secara alami. Memerlukan waktu yang sangat lama untuk membersihkan sampah plastik dari muka bumi. Terlebih lagi karena penggunaan plastik hampir tidak bisa dikendalikan. Plastik juga menjadikan suhu udara menjadi lebih panas dari ke hari, karena sifat polimernya yang tidak berpori. Pada saat ini, sebagian besar produk yang diproduksi tanpa memikirkan ke mana mereka akan pergi ketika dikonsumsi. Banyak produk yang juga dirancang untuk gagal dalam periode-tertentu yang dikenal sebagai "usang yang direncanakan". Filosofi desain ini adalah penyebab dibalik meluapnya tempat pembuangan sampah, pulau plastik di laut, dan menjadi momok seperti misalnya pembungkus, kemasan dan produk yang menyumbat ekosistem daerah. Ecobrick merupakan salah satu upaya kreatif untuk mengelola sampah plastik menjadi benda-benda yang berguna, mengurangi pencemaran dan racun yang ditimbulkan oleh sampah plastik.Ecobrick adalah salah satu usaha kreatif bagi penanganan sampah plastik. Fungsinya bukan untuk menghancurkan sampah plastik, melainkan untuk memperpanjang usia plastik-plastik tersebut dan mengolahnya menjadi sesuatu yang berguna, yang bisa dipergunakan bagi kepentingan manusia pada umumnya. Pembuatan ecobrick masih belum begitu populer di kalangan masyarakat luas. Sebagian besar masyarakat masih memperlakukan plastik-plastik bekas sebagai sampah plastik rumah tangga, mengotori lingkungan, sungai dan mencemari kehidupan sehari-hari tanpa adanya kesadaran diri.
\end{abstract}

Kata kunci: sampah plastik, pencemaran, ecobrick, upaya kreatif.

\section{Pendahuluan}

Plastik merupakan bahan recycle atau bahan yang bisa didaur ulang, maka dari itulah banyak cara pengolahan-pengolahan plastik. Selain itu plastik juga merupakan bahan kimia yang sulit terdegradasi atau terurai oleh alam, membutuhkan waktu beratus-ratus

\footnotetext{
* Koresponden penulis e-mail : sekar_happy08@yahoo.co.id
} 
atau bahkan ribuan tahun untuk menguraikan plastik oleh alam.

Plastik banyak digunakan dalam berbagai macam kebutuhan hidup manusia. Mulai dari bahan pembungkus makanan hingga keperluan bahan otomotif. Plastik merupakan sebuah bahan yang paling populer dan paling banyak digunakan sebagai bahan pembuat komponen otomotif selain bahan logam berupa besi. Permasalahan yang paling utama dari plastik adalah limbah plastik yang tidak bisa terurai secara alami. Memerlukan waktu yang sangat lama untuk membersihkan sampah plastik dari muka bumi. Terlebih lagi karena penggunaan plastik hampir tidak bisa dikendalikan. Plastik juga menjadikan suhu udara menjadi lebih panas dari ke hari, karena sifat polimernya yang tidak berpori.

Pada saat ini, sebagian besar produk yang diproduksi tanpa memikirkan ke mana mereka akan pergi ketika dikonsumsi. Banyak produk yang juga dirancang untuk gagal dalam periode-tertentu yang dikenal sebagai "usang direncanakan". Filosofi desain ini adalah penyebab dibalik meluapnya tempat pembuangan sampah, pulau plastik di laut, dan menjadi momok seperti misalnya pembungkus, kemasan dan produk yang menyumbat ekosistem daerah.

Bagi banyak perusahaan membuat sistem pengolahan limbah plastik memerlukan investasi besar-besaran dan restrukturisasi lengkap yang meliputi manufaktur, sumber bahan, dan menerapkan sistem baru untuk menyerap produk mereka. Transisi dapat menjadi sesuatu yang membingungkan.

\section{Bahan dan Metode}

Dewasa ini banyak ditemukan varian baru dalam dunia teknik mengenai macam-macam plastik. Masing-masing plastik memiliki sifat dan kegunaan yang berbeda-beda. Adapun macam-macam dari plastik itu sendiri adalah sebagai berikut.

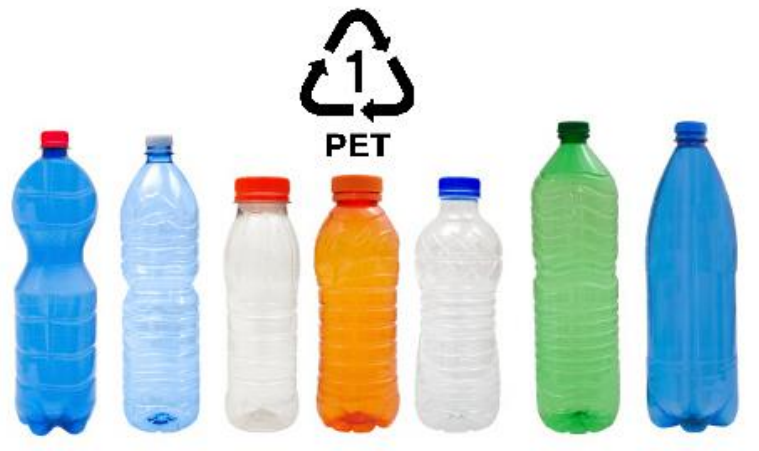

Gambar 1. Botol-botol plastik PET (Sumber: www.kswmesir.com)
PET (PolyEtylene Terephthalate). Material ini bersifat jernih, kuat, tahan bahan kimia dan panas, serta mempunyai sifat elektrikal baik yang Jika. Pemakaiannya dilakukan secara berulang, terutama menampung air panas, lapisan polimer botol meleleh mengeluarkan zat karsinogenik dan dapat menyebabkan kanker. PET digunakan sebagi pembungkus minuman berkarbonasi (soda), botol jus buah, peralatan tidur dan fiber tekstil (Gambar 1). PET memiliki sifat tidak tahan panas, keras, tembus cahaya (transparan), memiliki titik leleh $85^{\circ} \mathrm{C}$. Material ini dihasilkan dari kondensasi antara ethylene glycol dengan asam terepthalic dan termasuk pada tipe termoplastik. PET ini dapat dibentuk menjadi fiber seperti dacron dan film seperti mylar. Material PET ini merupakan plastik utama untuk pembuatan kantong kemasan makanan.

PP (PolyPropylene). Material ini memiliki sifat yang tahan terhadap bahan kimia atau Chemical Resistance, transparan dan memiliki titik leleh $165^{\circ} \mathrm{C}$. PP banyak digunakan pada kantong plastik, film, mainan, ember dan komponen-komponen otomotif. Variasi bentuk polypropylene memiliki kekerasan dan titik leleh yang berbeda-beda. Material PP ini diaplikasikan untuk pembuatan hiasan mobil, cashing accumulator, botol, tabung, dan tas (Gambar 2).
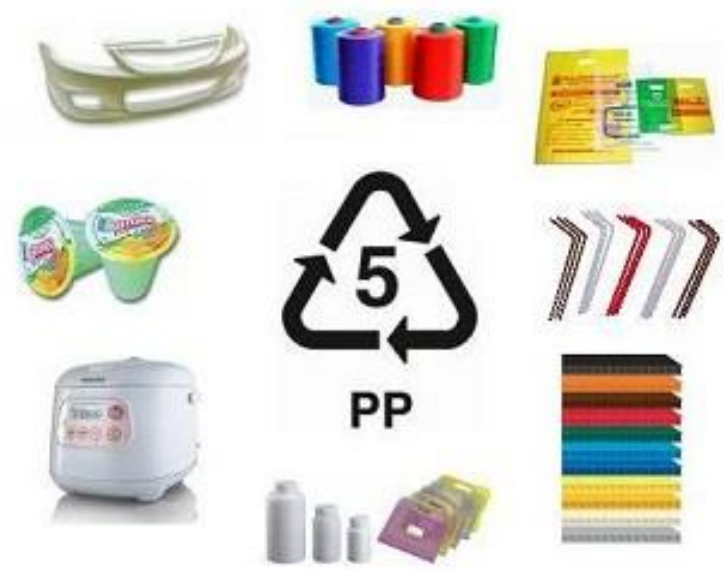

Gambar 2. Produk-produk yang menggunakan plastik jenis PP (Sumber: www.universal-polymer.com)

Beda lagi dengan PE (PolyEtylene) yang memiliki sifat-sifat di antaranya adalah permukaannya licin, tidak tahan panas, fleksibel, transparan/tidak dan memiliki titik leleh sebesar $115^{\circ} \mathrm{C}$. Maka dari itulah PE banyak digunakan sebagai kantong plastik, botol plastik, cetakan, film dan pada dunia modern digunakan untuk pembungkus kabel (Gambar 3). 


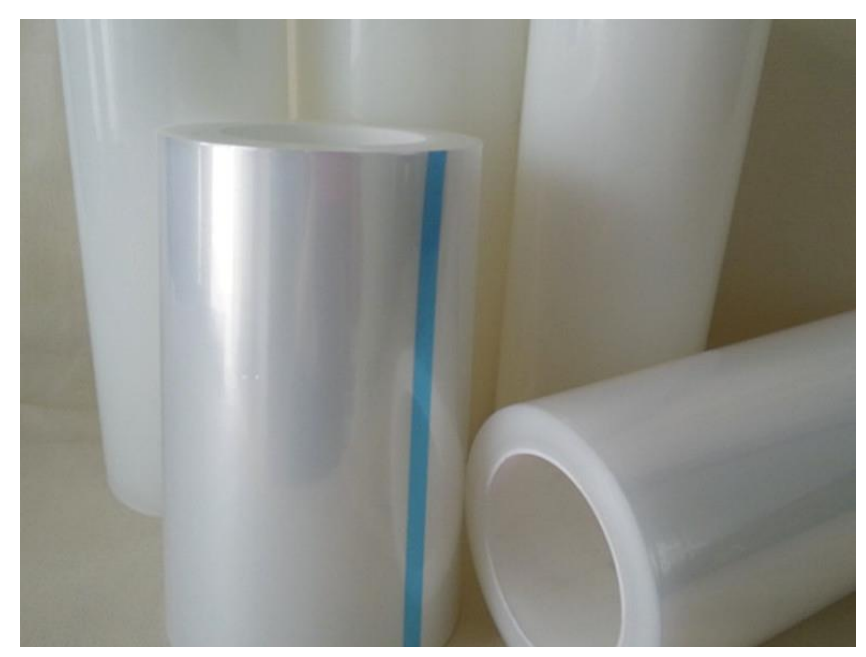

Gambar 3. Produk plastik PE (Sumber: www.protective-film.com)

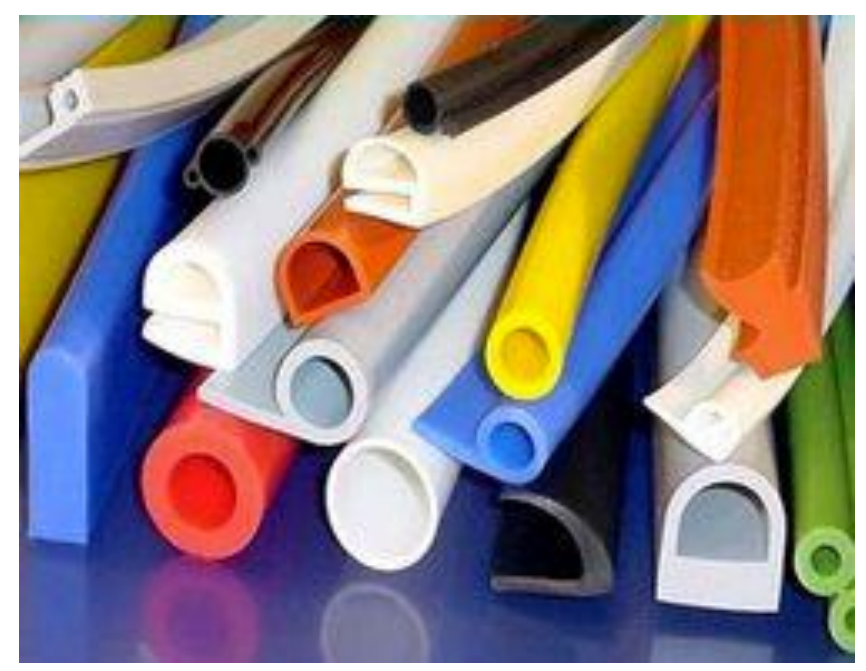

Gambar 4. Produk plastik PVC

(Sumber: www.primaxengineers.com)

PVC adalah Polyvinyl Chloride merupakan resin yang liat dan keras yang tidak terpengaruh oleh zat kimia lain (Gambar 4). Sifat dari PVC ini sendiri adalah keras, kaku, dapat bersatu dengan pelarut, memiliki titik leleh $70^{\circ}-140^{\circ}$ C. Kegunaan dalam kehidupan adalah sebagai pipa plastik (paralon), peralatan kelistrikan, dashboard mobil, atap bangunan dan lain-lain.

PS (Poly Styrene). Polymer ini mengandung bahan bahan Styrine yang berbahaya untuk kesehatan otak, mengganggu hormon estrogen pada wanita yang berakibat pada masalah reproduksi dan sistem saraf." Sifat-sifat yang dimiliki oleh PS adalah kaku, mudah patah, tidak buram dan memiliki titik leleh $95^{\circ} \mathrm{C}$. PS banyak digunakan sebagai penggaris plastik, cardridge printer, rambu-rambu lalu lintas dan gantungan baju. Material ini juga diaplikasikan untuk pembuatan furnitur (pelapis kayu), cashing monitor komputer, cashing TV, cashing/tempat CD, utensil, lensa (optik dari plastik) (Gambar 5). Bilamana polystyrene dipanaskan dan udara ditiupkan maka melalui pencampuran tersebut akan terbentuk styrofoam. Styrofoam memiliki sifat sangat ringan, moldable dan merupakan insulator yang baik.

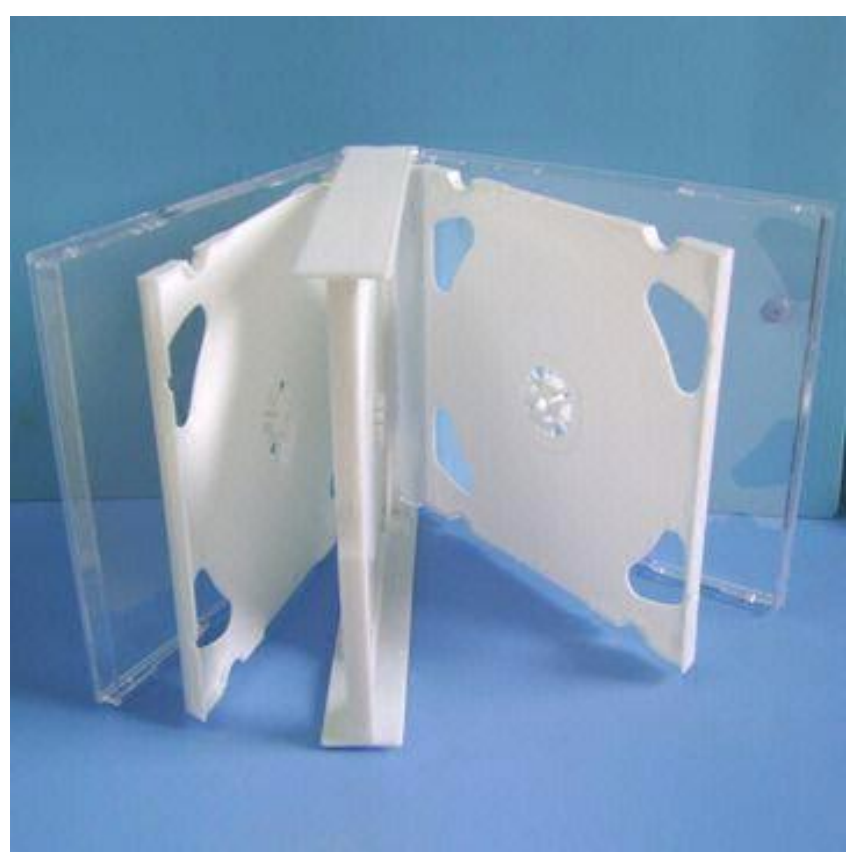

Gambar 5. Tempat CD yang terbuat dari plastik jenis PS (Sumber: www.globalsources.com)

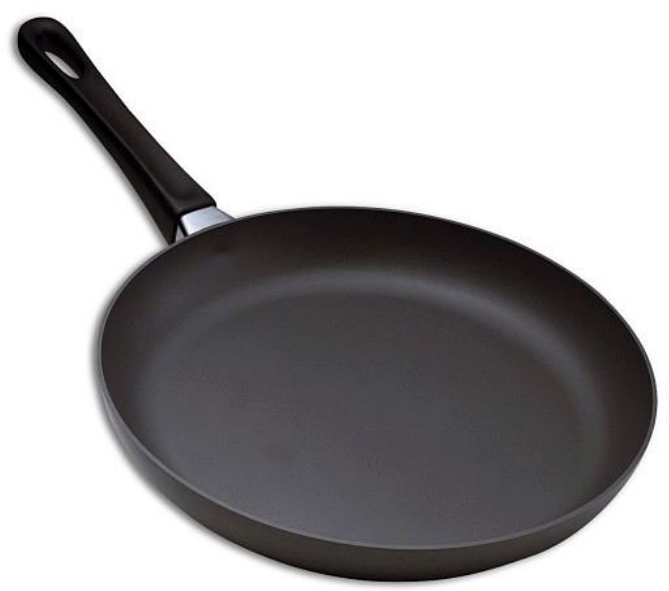

Gambar 6. Plastik jenis PTFE (Teflon) yang digunakan untuk melapisi alat penggorengan.

(Sumber: www.cookingforengineers.com) 


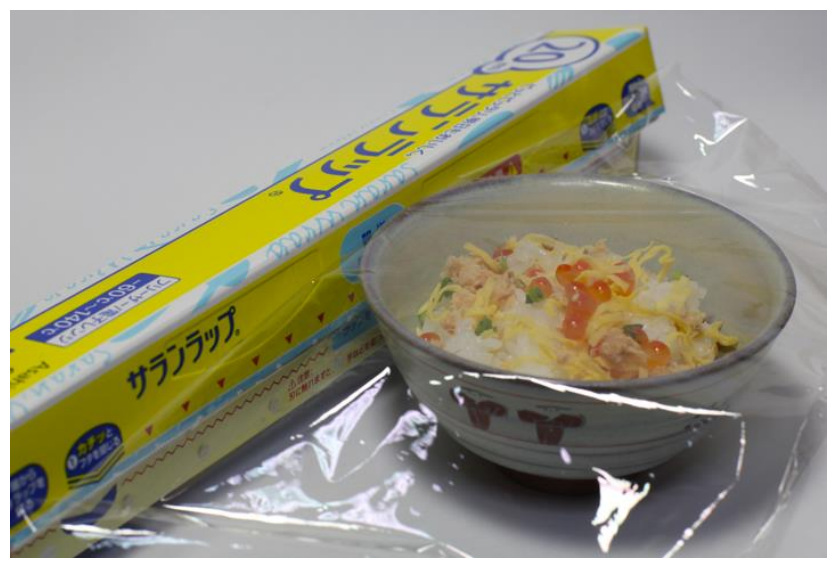

Gambar 7. Plastik Saran yang digunakan untuk pembungkus makanan (wrapping)

(Sumber : Foto oleh Sekartaji 2016)

Bahan plastik yang lain adalah polytetrafluoroethylene (PTFE-Teflon). Polimer ini bersifat stabil, tahan panas, kuat, tahan terhadap berbagai bahan kimia dan permukaannya sangat licin (hampir tidak ada gesekan). Teflon ini digunakan diantaranya untuk peralatan masak, pelapis tahan air, film, bearing (bantalan poros) dan tabung /pipa. Gambar 6 menunjukkan contoh produk panci berbahan lapisan teflon.

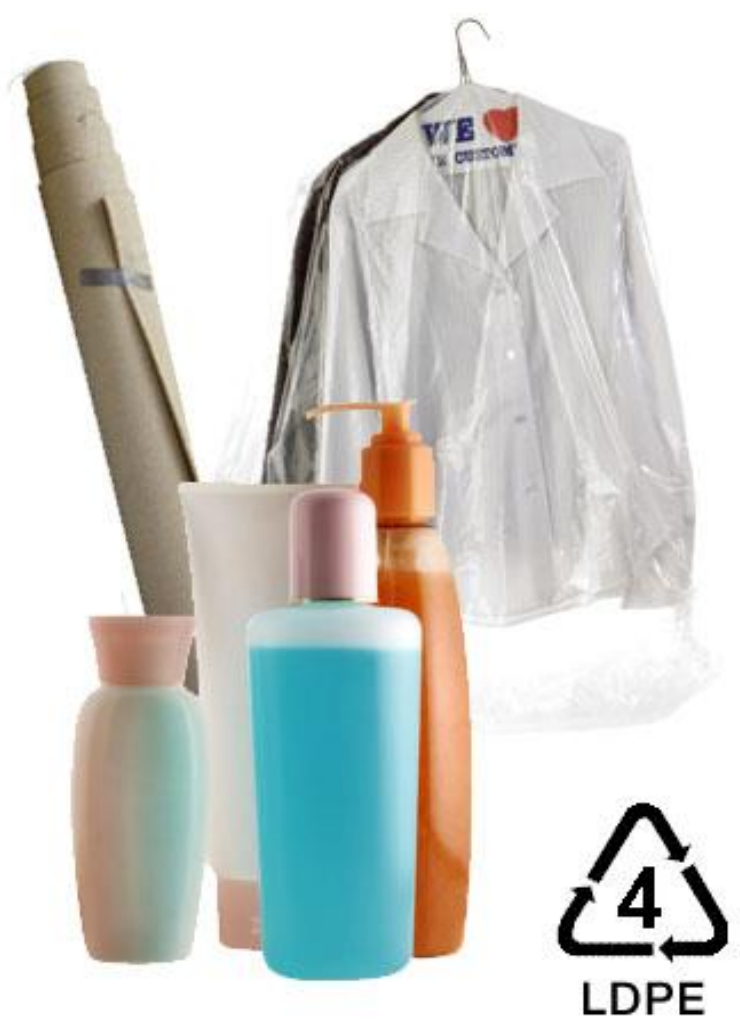

Gambar 8. Produk yang terbuat dari plastik LDPE (Sumber: www.hopkinsmn.com)

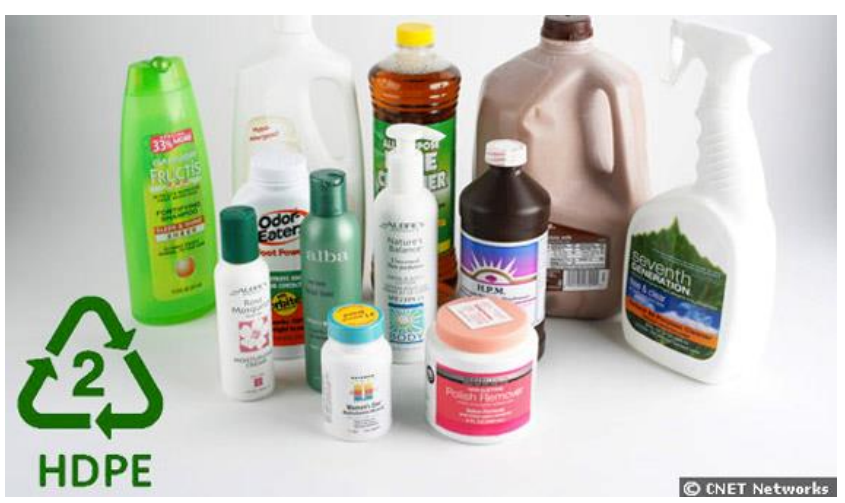

Gambar 9. Produk botol yang dibuat dari plastik HDPE (Sumber: www.khba.wordpress.com)

Bahan plastik yang cukup populer adalah Polyvynilidine Chloride (Plastik Saran). Polimer ini dapat dibentuk ke dalam bentuk film dan lembaran panjang. Plastik saran sangat populer digunakan untuk pembungkus makanan. Gambar 7 memperlihatkan contoh penggunaan produk plastik saran untuk wrapping makanan.

Material plastik lainnya adalah LDPE dan HDPE. Karakteristik LDPE (Low Density Polyethylene) ialah sifatnya yang lunak dan fleksibel sehingga pertamakali diaplikasikan sebagai isolator kawat listrik. Namun saat ini aplikasinya telah berkembang diantaranya untuk pembuatan film, wraps (pembungkus makanan), botol, kantong sampah, dan sarung tangan yang sekali pakai buang (Gambar 8). Sedangkan plastik HDPE (High Density Polyethylene) ini keras dan memiliki titik lebur lebih tinggi dibandingkan LDPE. Selain itu, material ini tenggelam dalam larutan campuran air dengan alkohol. Material ini sering diaplikasikan untuk pembuatan hula hoop dan kontainer (Gambar 9).

Sedangkan material plastik lain yang akrab dengan kehidupan manusia sehari-hari adalah Polymethylmethacrylate (PMMA) atau dikenal dengan nama Acrylic. Acrylic diketahui untuk digunakan dalam cat dan fiber sintetik seperti fake fure, dalam bentuk padatan bahan ini memiliki sifat keras dan lebih transfaran daripada gelas. Bahan ini sering dijual sebagai bahan pengganti gelas dengan merk dagang plexiglas atau lucite. Bahan ini diaplikasikan untuk pembuatan kanopi pesawat terbang dan casing handphone (Gambar 10).

Material plastik lainnya yang cukup dikenal di tengah masyarakat adalah polyurethane. Material ini diaplikasikan untuk pembuatan mattress, pelapisan dan bahan pengisi furnitur, isolasi panas dan untuk bahan pakaian olah raga (lycra). Gambar 11 menunjukkan penggunaan bahan polyurethane untuk produk kursi. 


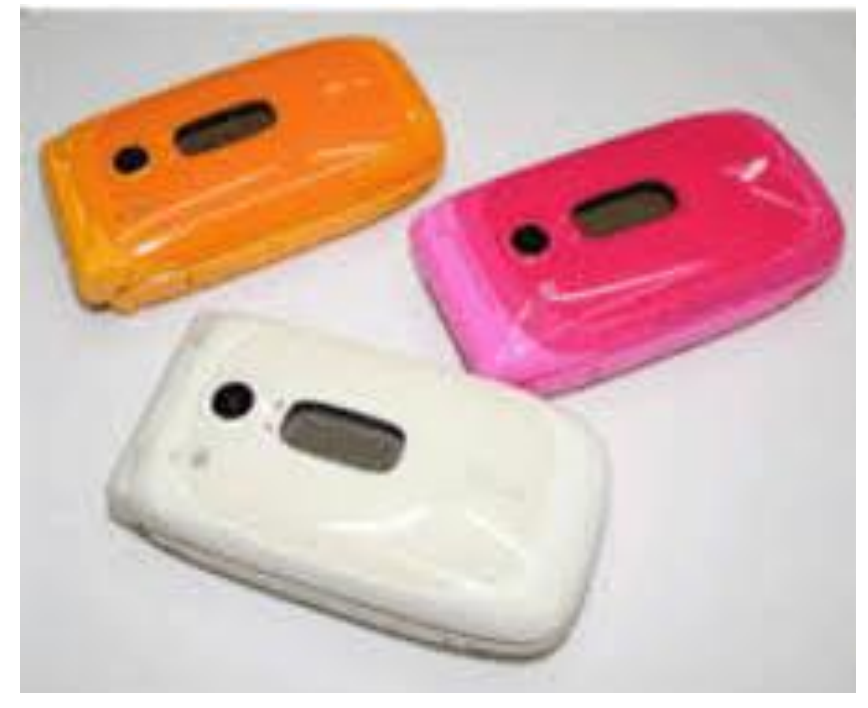

Gambar 10. Cashing handphone yang terbuat dari plastik acrylic (PMMA) (sumber: www.dynachemplastic.com)
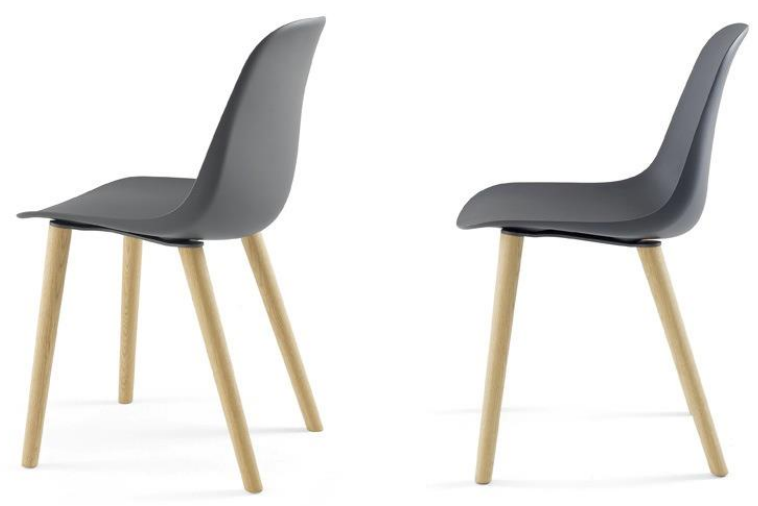

Gambar 11. Kursi yang dibuat dari perpaduan kayu dan plastik jenis polyurethan

(Sumber: www.idfdesign.com)

Masing-masing jenis plastik di atas memiliki fungsi dan sifat yang berbeda satu dengan yang lainnya. Selain itu, pada masing-masing material, terdapat simbol segitiga yang disebut simbol daur ulang. Setiap simbol memiliki makna yang mencerminkan sifat atau karakter daur ulang material tersebut. Tabel berikut ini memperlihatkan perbandingan sifat beberapa contoh resin thermosetting dan thermoplastik komersial yang digunakan sebagai bahan baku produk yang sering dijumpai dan digunakan oleh masyarakat umum.

Tabel 1. Properti plastik

\begin{tabular}{|c|c|c|c|}
\hline Simbol Daur Ulang & Jenis Plastik & Sifat-sifat & Aplikasi kemasan \\
\hline & $\begin{array}{l}\text { Polietilen } \\
\text { Tereftalat } \\
\text { (PET, PETE) }\end{array}$ & $\begin{array}{l}\text { Bening, kuat, tangguh } \\
\text { non permeabel } \\
\text { (gas dan uap air) }\end{array}$ & $\begin{array}{l}\text { Soft drink, botol air-salad } \\
\text { keju kacang }\end{array}$ \\
\hline & $\begin{array}{l}\text { High Density } \\
\text { Polietilen }\end{array}$ & $\begin{array}{l}\text { Kaku, kuat, tangguh, } \\
\text { tahan lembab. }\end{array}$ & $\begin{array}{l}\text { Susu, jus buah, } \\
\text { kantong belanja }\end{array}$ \\
\hline & $\begin{array}{l}\text { Polivinil Klorida } \\
\text { (PVC) }\end{array}$ & $\begin{array}{l}\text { Tangguh, kuat, } \\
\text { mudah dicampur }\end{array}$ & $\begin{array}{l}\text { Botol jus, pipa air } \\
\text { bungkus plastik }\end{array}$ \\
\hline & $\begin{array}{l}\text { Low Density } \\
\text { Polietilen } \\
\text { (LDPE) }\end{array}$ & $\begin{array}{l}\text { Mudah diproses, kuat } \\
\text { tangguh, fleksibel, } \\
\text { mudah disegel, tahan } \\
\text { lembab }\end{array}$ & $\begin{array}{l}\text { Kantong makanan beku, } \\
\text { botol remas (kecap, saus, } \\
\text { madu), bungkus plastik }\end{array}$ \\
\hline & $\begin{array}{l}\text { Polipropilen } \\
\text { (PP) }\end{array}$ & $\begin{array}{l}\text { Kuat, tangguh, } \\
\text { tahan panas, minyak } \\
\text { bahan kimia, } \\
\text { tahan lembab }\end{array}$ & $\begin{array}{l}\text { Peralatan dapur, peralatan } \\
\text { microwave, wadah yoghurt, } \\
\text { piring dan mangkok sekali } \\
\text { pakai }\end{array}$ \\
\hline & $\begin{array}{l}\text { Polistiren } \\
\text { (PS) }\end{array}$ & $\begin{array}{l}\text { Mudah dibentuk dan } \\
\text { diproses }\end{array}$ & $\begin{array}{l}\text { Karton telur, stirofom, } \\
\text { mangkuk sekali pakai }\end{array}$ \\
\hline & $\begin{array}{l}\text { Plastik lain } \\
\text { (Polikarbonat } \\
\text { atau ABS) }\end{array}$ & $\begin{array}{l}\text { Tergantung dari jenis } \\
\text { polimernya }\end{array}$ & $\begin{array}{l}\text { Botol minuman, botol } \\
\text { susu bayi, barang-barang } \\
\text { elektronik }\end{array}$ \\
\hline
\end{tabular}

\section{Hasil dan pembahasan}

Ecobricks, memberikan langkah perantara yang berharga dalam transisi ini. Ecobricks pada dasarnya menangkap semua siklus hara teknis dan bahan nonbiodegradable. Ecobricks memungkinkan desainer untuk membuat langkah pertama bagi pembentukan desain cradle-to-cradle. Dengan pemikiran dan perencanaan terlebih dahulu, produk mereka dapat dibuat dengan mudah dan efektif atau disebut juga dengan produk yang Ecobrickable.

Tidak ada lisensi, sertifikat atau tes resmi untuk membuat produk Ecobrickable. Ini adalah goodwill desain yang diharapkan bisa menyelamatkan kehidupan manusia dari sampah plastik.

Sesuatu telah bergeser di sini. Sampah, digunakannya plastik, yang sebelumnya hanya dirawat atau ditangani oleh orang-orang tertentu (pemulung, orang-orang dari kelas lebih rendah, kotor dan gelap dari berbagai tempat), sekarang berubah. Melalui ecobricks, lebih banyak orang, lebih banyak kelompok, tidak peduli apa kelas sosial mereka, menjadi tertarik untuk bekerja pada sampah plastik, terutama yang digunakan dalam kehidupan sehari-hari. Lokakarya telah dilakukan di setiap kantor desa, rumah penduduk, di kompleks masjid 


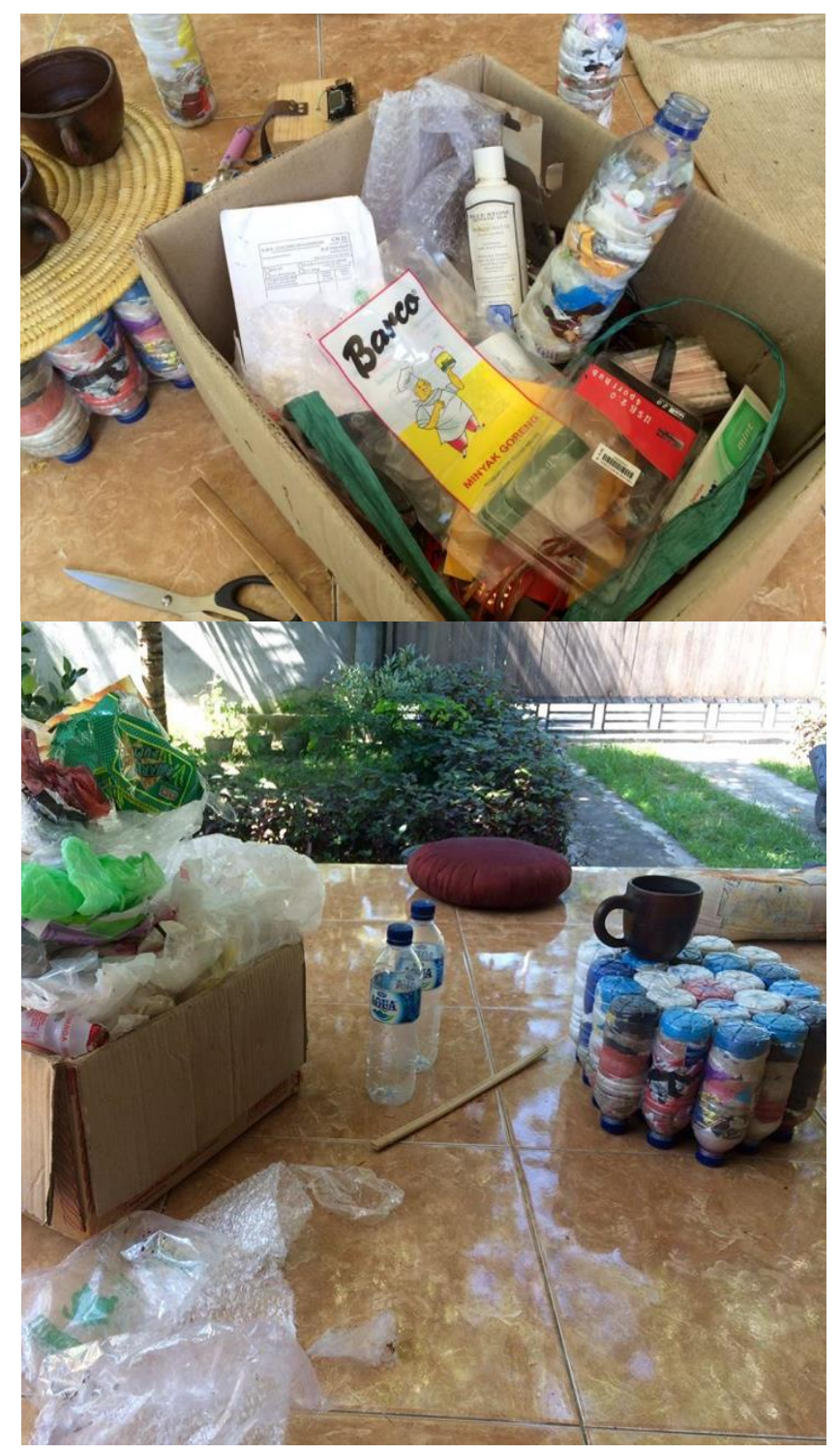

Gambar 12. Beberapa jenis sampah rumah tangga yang bisa digunakan untuk membuat ecobrick (Sumber Foto : Sekartaji, 17 Mei 2016)

Tidak hanya itu, yang paling penting dan melegakan adalah bahwa, orang-orang mulai memahami mengapa kita perlu ecobrick. Apa dasar dan filosofi di balik melakukan kerja keras ini? pengetahuan yang lebih komprehensif tentang plastik, fakta-fakta dari produksi plastik, tentang masalah daur ulang ini, apa bahaya saat kita melakukan hal yang salah dengan plastik, apa efek ke lingkungan kita jika kita tidak sadar, apa yang akan terjadi dalam waktu dekat dan jangka panjang jika kita tidak peduli tentang mereka, bagaimana kita perlu mengubah gaya hidup kita dan perilaku konsumsi kita, dan apa yang bisa kita lakukan dengan plastik atau sampah yang digunakan dan bahkan membuat mereka sebagai bagian dari solusi.

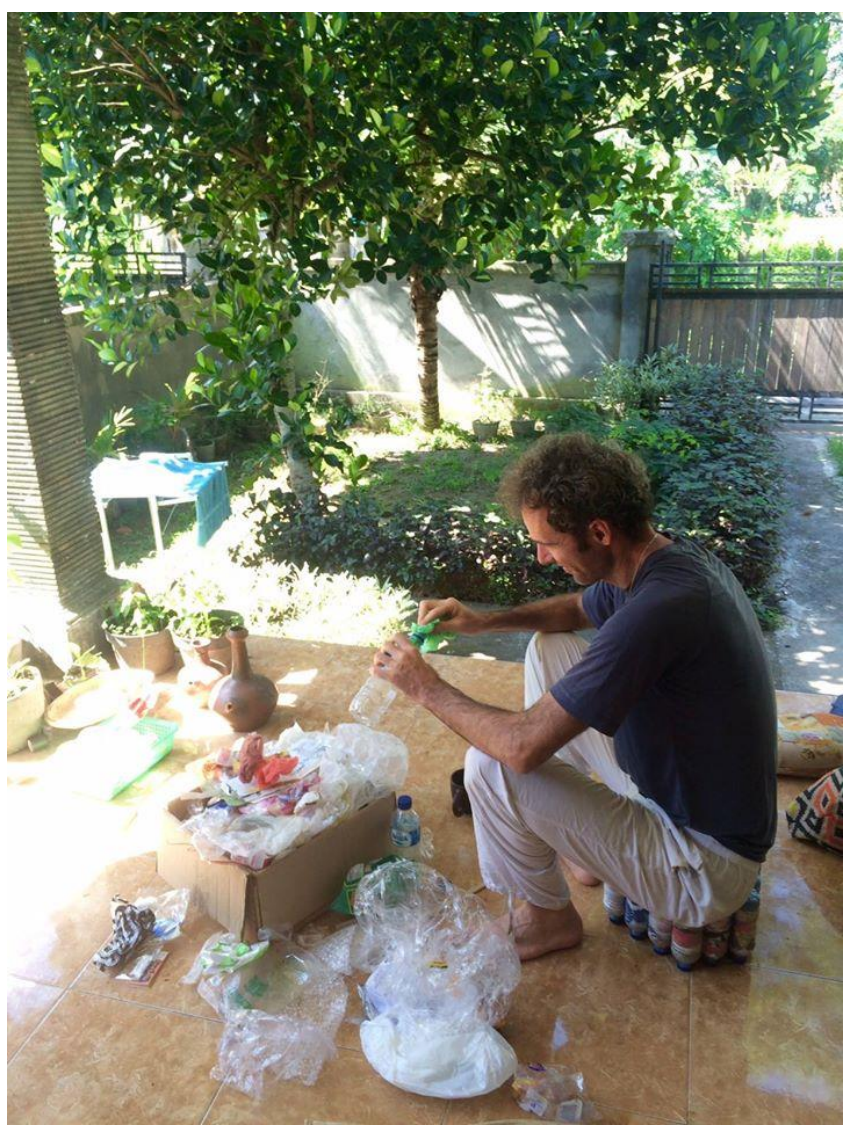

Gambar 13. Russell Maier sedang membuat ecobrick di kediamannya di Ubud, Bali

(Sumber Foto : Sekartaji, 17 Mei 2016)

Sebenarnya itulah targetnya. Bukan hanya bagaimana mengelola plastik yang selama ini terus dikonsumsi, bukan hanya bercita-cita membangun atau membentuk sesuatu dengan ecobricks, tapi soal mengurangi konsumsi plastik dan sebisa mungkin tak memakainya. Dan bagaimana membangun kesadaran secara massal, menjadi gerakan masyarakat di segala lini dan jalur, karena membuat ecobricks tidak membutuhkan skill khusus, dan tanpa biaya, karena berangkat dari bekas konsumsi sehari-hari, bisa dilakukan kapan saja, dan bisa juga dikerjakan bersama-sama maupun sendiri sambil melakukan kegiatan sehari-hari lainnya, sembari mengisi waktu. Bukan sekedar menghindari bahan kimia dan memastikan mengkonsumsi segala sesuatu lebih sehat dan alami, namun yang jadi alasan adalah bahwa produk-produk itu semua hampir selalu dikemas dalam bungkus plastik, yang memang susah kita ecobricks: botol sampo, tube pasta gigi, sabun cair, dan lain sebagainya.

Ketika membuat ecobricks dari segala jenis sampah yang dihasilkan sehari-hari, bahkan ketika sudah dipilah-pilah pun, kesadaran bahwa semua "bakal racun" itu nantinya akan berakhir di lingkungan 


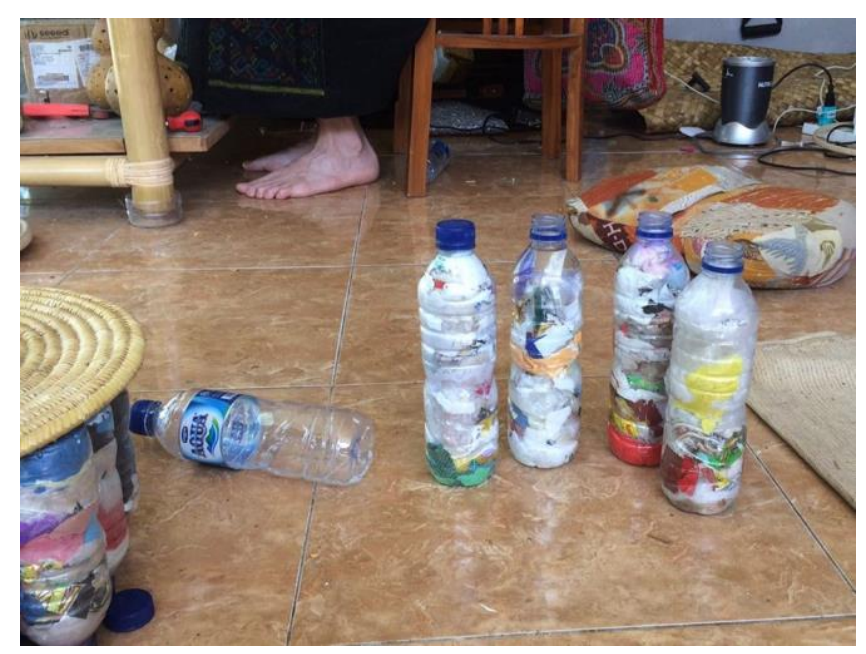

Gambar 14. Tahap pertama, yaitu memampatkan plastikplastik kemasan ke dalam botol plastik hingga benar-benar padat (Sumber foto : Sekartaji, 17 Mei 2016)

Membuat ecobricks rutin seminggu sekali atau dua ketika sampah plastik menggunung, saat itulah kesadaran membesar dan keprihatinan hadir: betapa susahnya memasukkan sendok plastik di dalam botol, susahnya memadatkan styreofoam dari bekas bungkus makan salah satu resto, susahnya memasukkan mika plastik dari bekas bungkus kabel data atau kabel audio, susahnya meng-ecobrick tube bekas pasta gigi, maupun beberapa botol kertas yang dilapis plastik seperti karton susu, yang bahkan ada bagian metal atau logam juga di tutupnya, atau sedikit plastik di lubangnya.

Munculnya suatu kesadaran bahwa ada beberapa kemasan yang sangat susah dikerjakan karena berbahan campur-campur, dan susah untuk diecobrick, sedangkan ecobricks sejauh ini jadi satusatunya solusi menjebak plastik agar tak berkeliaran di lingkungan dan bumi ini.Benar, hanya dengan menjadikan ecobricking atau membuat ecobricks ini sebagai kebiasaan, hanya pada saat itulah kesadaran akan konsumsi plastik dan kebutuhan untuk melindungi lingkungan dari racun plastik terasa. Sedangkan jelas-jelas, mempercayakan tempat sampah, truk sampah, bak sampah, tak akan mempengaruhi apa pun, bahkan akan berakhir lebih mengerikan.

Seolah sudah memilah, sudah memastikan sampah tersebut di keranjang yang benar, sudah melihat bahwa keranjang itu diangkut truk, lalu ke mana truk itu pergi? Ke sanalah sampah plastik kita akan menggunung dan menjadi sumber cemar lebih besar lagi bagi lingkungan, kota, pulau, bumi ini.

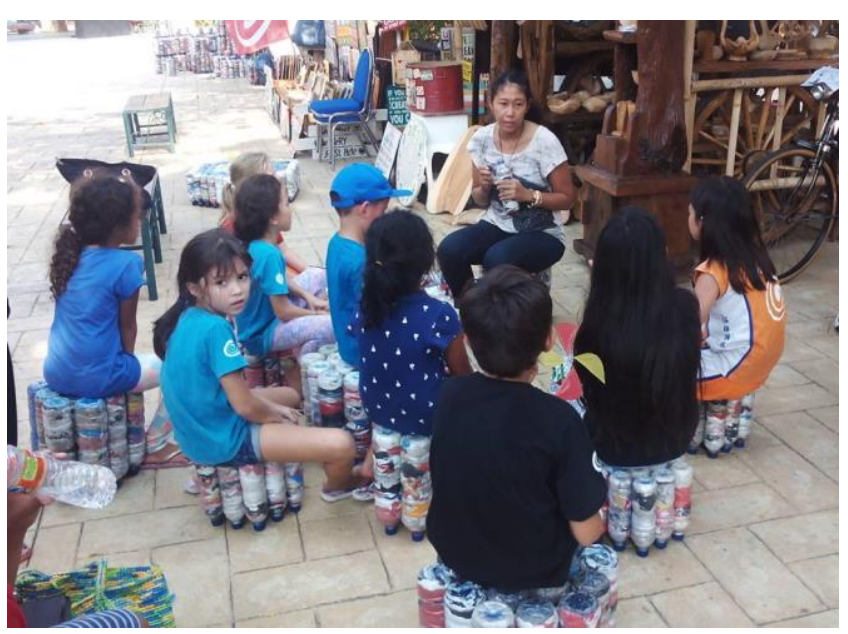

Gambar 15. Hasil ecobrick bisa digunakan sebagai pengganti bangku

(Sumber foto : Sekartaji, Februari 2016)

Bahkan ketika mencoba mendaur ulang, tak lebih hanya menunda ketibaan akhir sampah plastik ke proses pencemaran tanah, udara, air dan tanaman dan hutan dan bahan pangan dan diri dan tubuh kita atau ibu-ibu hamil atau bayi-bayi yang baru lahir atau yang akan lahir. Hanya dari sampah rumah tangga, yang dipakai sendiri, bermula dari sana, akan makin sadar dan hati-hati lalu mengurangi konsumsi kita akan plastik.

\section{Mengapa Perlu Membuat Ecobrick?}

Plastik terbuat dari petro-kimia. Bahan kimia ini tidak cocok bagi ekologi. Studi ilmiah menunjukkan bahwa bahan kimia ini beracun untuk manusia, kita tahu ini ketika kita mencium plastik terbakar. Seiring waktu, ketika bahan kimia ini larut ke dalam tanah, air dan udara, mereka diserap oleh tanaman dan hewan yang pada akhirnya akan diserap juga oleh manusia, menyebabkan cacat lahir, ketidakseimbangan hormon, dan kanker. Sampah plastik yang berserakan, dibakar atau dibuang akan menghasilkan bahan kimia beracun. Bahkan rekayasa TPST (Tempat Pembuangan Sampah Terakhir) juga tidak bisa menjadi solusi yang baik. Dalam waktu sepuluh tahun, atau bahkan seratus tahun, bahan kimia ini pada akhirnya akan meresap ke dalam biosfer, yang mempengaruhi peternakan dan kehidupan manusia.

Plastik tidak terurai, mereka photodegrade. Ini berarti bahwa plastik perlahan-lahan akan pecah menjadi potongan-potongan kecil-kecil kemudian meresap ke dalam tanah atau air. Karena potonganpotongan ini sangat kecil mereka mudah diserap oleh tanaman, ikan dan hewan yang kita makan. 


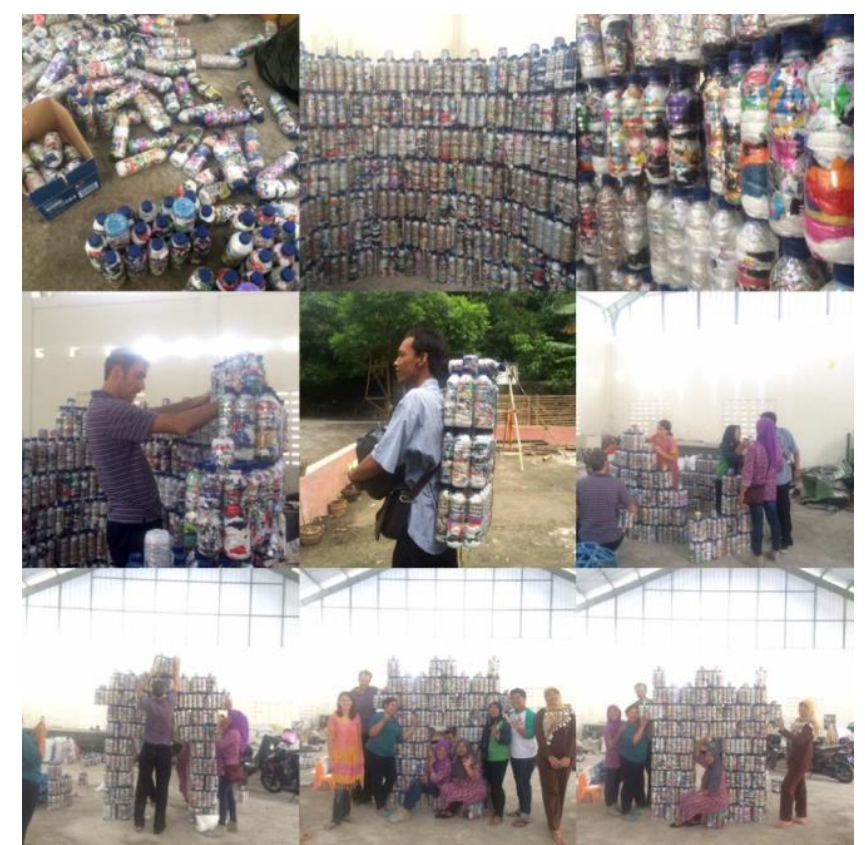

Gambar 16. Beberapa kegiatan Komunitas Mukabumi mengenai pembuatan ecobrick di beberapa tempat di Yogyakarta

(Sumber foto: Sekartaji, Februari-Mei 2016)

Para ilmuwan mulai menyadari betapa banyak plastik dan non-biodegradables lainnya saat ini yang berserakan di laut. Banyak penelitian yang menunjukkan efek buruk pada hewan laut dan ekologi. Para ilmuwan juga menemukan efek mengerikan pada tubuh manusia bahwa bahan kimia yang membentuk plastik terserap ke dalam tubuh manusia. Bahan kimia seperti Biphenyl A dan Phalates sekarang dilarang digunakan pada produk-produk tertentu di Amerika dan Eropa. Namun, kimia ini terus digunakan secara luas di Filipina dan negara-negara Asia lainnya. Bahkan jumlah yang sangat kecil dari bahan kimia ini memiliki efek buruk pada manusia dan menyebabkan alergi, ketidakseimbangan hormonal, kanker serta keracunan akut. Anak-anak pada usia muda adalah yang paling rentan terkena efek buruknya. Ketika plastik dibakar, petrokimia di dalamnya bergabung membentuk dioksin. Dioksin adalah racun buruk dan mencemari baik udara melalui asap maupun bumi dan air melalui abu.

Plastik harus dihilangkan atau diolah sebaik mungkin, atau diletakkan di tempat yang tepat. Menyimpan plastik sama artinya dengan mengurangi dampak racun yang menyebar dan merusak hidup mahluk hidup. Botol PET akan bertahan selama 300500 tahun jika mereka disimpan di tempat yang terlindung dari sinar matahari. Ecobricks memungkinkan kita untuk mengubah garis produk polusi dalam lingkaran.
Beberapa pedoman berkaitan dengan Ecobrickable, adalah: (1) Produk tidak mengandung zat-zat yang akan menimbulkan korosi bagi plastik PET dari waktu ke waktu. (2) Produk dapat dibongkar/dipotong menjadi bagian-bagian yang dapat ditampung dalam leher dengan diameter $22 \mathrm{~mm}$ dari botol PET standar (kelas A Ecobrick). (3) Produk tidak mengandung protusions/bentuk tajam yang bisa menusuk seorang yang mengerjakan Ecobrick dari dalam saat sedang dikemas (misalnya kaca, logam). (4) Produk tidak mengandung bahan kimia reaktif, atau jika demikian, komponen ini jelas ditandai sebagai un-Ecobrickable. (5) Produk tidak mengandung kertas, cairan atau bahan-bahan lain selain plastik. (6) Produk bisa masuk dalam leher/bidang dengan diameter atau ukuran 10-20 cm(Ecobrick Kelas B). Hasil pembentukan ecobrick memberikan hasil yang dapat digunakan dalam kehidupan sehari-hari.

Tidak ada buku manual dalam pembuatan ecobrick. Begitu juga tidak ada petunjuk khusus dalam pembuatan ecobrick. Namun demikian harus tetap memperhatikan pedoman utama dalam pembetukan desain ecobrick. Namun demikian ada cara-cara tertentu yang dilakukan oleh beberapa pelaku pembuat ecobrick, seperti Russell Maier dan Ani Himawati dengan komunitas Mukabumi yang beberapa tahun terakhir ini aktif mensosialisasikan pembuatan ecobrick di berbagai tempat, seperti Jakarta, Yogyakarta, Bali dan Philipina. Selain Russel Maier dan Ani Himawati, ada beberapa pemerhati lingkungan yang juga menerapkan sistem ecobrick untuk "membersihkan" lingkungan dari sampah plastik, diantaranya adalah Susanna Heise di Guatemala pada tahun 2014, Alvaro Molina di kepulauan Ometepe pada tahun 2003, dan seorang arsitek Jerman, Andreas Foese di Amerika Selatan pada tahun 2000.

Membuat ecobrick tidak sulit, hanya memerlukan ketelatenan dan sedikit usaha. Secara umum langkahlangkah membuat ecobrick adalah sebagai berikut :

1. Mengumpulkan botol-botol plastik bekas, seperti botol bekas kemasan minuman (misalnya air mineral), botol bekas kemasan minyak goreng dan lain sebagainya. Kemudian mencucinya hingga bersih, lalu dikeringkan.

2. Mengumpulkan berbagai macam kemasan plastik, seperti kemasan mie instan, minuman-minuman instan, plastik pembungkus, tas plastik dan sebagainya. Harus dipastikan plastik-plastik tersebut bebas dari segala jenis makanan (yang tersisa didalamnya), dalam keadaan kering dan tidak tercampur oleh bahan lain (klip, benang, kertas dan sebagainya).

3. Memasukkan segala jenis plastik yang ada di poin ke 2 ke dalam botol-botol plastik pada poin ke 1 . 
4. Tidak boleh tercampur dengan kertas, kaca, logam, benda-benda yang tajam dan bahan-bahan lain selain plastik.

5. Bahan-bahan plastik yang dimasukkan ke dalam botol plastik harus dimampatkan hingga sangat padat dan mengisi seluruh ruangan dalam botol plastiknya.

6. Cara memadatkannya bisa dengan menggunakan alat yang terbuat dari bambu atau kayu (seperti tongkat bambu atau kayu).

7. Jika ingin membuat sesuatu dengan hasil ecobrick ini, misalnya membuat meja, kursi, atau bendabenda lain, maka bisa menggunakan botol-botol yang berukuran sama, atau bahkan dari jenis dan merk yang sama, sehingga memudahkan penyusunan.

8. Jika menginginkan hasil yang berwarna-warni, maka plastik-plastik kemasan yang disusun didalamnya bisa diatur sedemikian rupa sehingga menghasilkan warna sesuai yang diinginkan. Bisa juga dengan cara membungkus botol plastik dengan cellophone/pita perekat yang berwarna.

9. Setelah semua botol plastik diisi dengan kemasankemasan plastik hingga padat, maka botol-botol plastik tersebut siap disusun dan digabungkan menjadi benda lain, seperti meja, kursi, bahkan dinding dan atau lantai panggung, pembatas ruangan dan banyak lagi lainnya.

Untuk merekatkan satu botol dengan botol yang lainnya bisa menggunakan lem adesive atau bahan semen/gibs. Supaya bisa merekat kuat, botol-botol tersebut diikat kuat-kuat dengan menggunakan tali atau benang. Penggunaan tali rafia akan memberikan efek warna yang bagus sekaligus mengurangi sampah plastik dari jenis lain.

\section{Kesimpulan}

Plastik merupakan sampah yang sangat sulit untuk diuraikan secara alami, sehingga menjadi dilema selama bertahun-tahun. Para ilmuwan, pakar ekologi dan pemerhati lingkungan hidup telah berupaya dengan berbagai cara untuk menanggulangi persoalan sampah plastik ini.

Ecobrick adalah salah satu usaha kreatif bagi penanganan sampah plastik. Fungsinya bukan untuk menghanucrkan sampah plastik, melainkan untuk memperpanjang usia plastik-plastik tersebut dan mengolahnya menjadi sesuatu yang berguna, yang bisa dipergunakan bagi kepentingan manusia pada umumnya.

Pembuatan ecobrick masih belum begitu populer di kalangan masyarakat luas. Sebagian besar masyarakat masih memperlakukan plastik-plastik bekas sebagai sampah plastik rumah tangga, mengotori lingkungan, sungai dan mencemari kehidupan sehari-hari tanpa adanya kesadaran diri.

Untuk itu kiranya perlu adanya sosialisasi yang lebih intensif mengenai upaya pengolahan kreatif sampah plastik ini. Dimulai dari sampah plastik rumah tangga. Dengan sedikit usaha, satu masalah penting akan terurai sedikit demi sedikit.

\section{Daftar pustaka}

Barnes, David K. A.; Galgani, Francois; Thompson, Richard C.; Barlaz, Morton (2009) Accumulation and Fragmantation of Plastic Debris in Global Environments. UK: The Royal Society, Biological Sciences Press

Dison, Gina (2014). Dep Ed Usec Graces eco-brick launching in Apayo. Northern Philippine Times. 11 Juli 2014

Fenichell, Stephen (1996) Plastic: The Making of a Synthetic Century. UK: Harper Business Ltd.

Halden, Rolf U. (2010) Plastics and Health Risks. The Annual Review of Public Health. 31 pp 179-94

Himawati, A. (2015) Meng-Ecobrick di Rumah Sendiri. Yogyakarta: Penerbit Kendi Aksara

Neeti, Rustagi, Pradhan, S. K. \& Singh, Ritesh (2011). Public Health Impact of Plastic: An Overview. Journal of Occupational and Environmental Medicine. Sep-Dec $2011 \mathrm{Vol}$ 15(3) pp 100-103

Weisman, Alan (2010) The World Without Us. Toronto: Harper Collins Canada 
Sekartaji Suminto Ecobrick: Solusi Cerdas dan Kreatif untuk Mengatasi Sampah Plastik 